\title{
CREATING THE CRISIS MANAGEMENT SYSTEM IN SMALL ORGANISATIONS - TOPICS
}

\author{
[Vytvoření systému krizového managementu v malých organizacích - námět]
}

\author{
Marie Mikušová ${ }^{1}$ \\ ${ }^{1}$ Vysoká škola báňská-Technická univerzita Ostrava, Ekonomická fakulta, Sokolská 33, 70121 Ostrava \\ Email:marie.mikusova@vsb.cz.
}

\begin{abstract}
In this article simple and understandable framework for the creation of the crisis management system is presented. When creating framework two premises were respected - crisis management is seen as a system and as a process. Mind map in which substantial causal relation were captured is default for framework creating. Framework is prepared to engage a sequence of individual steps, the reason for their implementation, dates and responsible person/team. Presented framework is a tool for the practice of managers, especially those of small organisations. It has been successfully applied in several small organisations.
\end{abstract}

Keywords: crisis management, framework, mind map, small organisation, system.

JEL classification: M19, M21

Received: 23.12.2020; Reviewed: 14.1.2021; 20.1.2021; Accepted: 19.5.2021

\section{Úvod}

V posledních letech se povědomí o krizích zvyšuje, stejně jako znalosti podmínek, které jsou výsledkem změn trhu, ekonomiky i samotných organizací. Ty jsou stále více zranitelné díky selháním předvídání a kontroly. Vědci i praktici usilují o rozvoj krizového managementu v teoretické i praktické rovině. Důvodem je podpořit top management předvídat a předcházet krizím, což je důležitou podmínkou pro chod organizace.

Po krátkém teoretickém vymezení řešené problematiky, kterou je krize a její řízení, je představen rámec pro tvorbu systému krizového managementu $\mathrm{v}$ organizaci. $\mathrm{Na}$ základě myšlenkové mapy jsou postupně popisovány prvky systému krizového managementu a jejich provázanost. U každého prvku je udán důvod jeho zařazení do systému, odpovědná osoba, která se mám tímto prvkem zabývat, přibližně v jakém termínu a podklady, ze kterých bude vycházet. Tento rámec $\mathrm{v}$ prezentované zkrácené podobě nelze považovat za metodiku, avšak i tak může sloužit jako praktický nástroj především pro manažery malých organizací.

\section{Předmět a cíl výzkumu}

Krizový management znamená systematický a komplexní př́stup v rámci aktivit organizace. Musí být propojen se strategickým řízením (Bergeron, Cooren 2012). Často probíhá souběžně s řízením standardním. Zavedení systému krizového managementu je náročné časově i zdrojově. Na tuto bariéru narážejí především malé organizace (Zapletalová et al. 2015). Skutečnost, že i malé organizace akceptují ve zvyšující se miřre nutnost krizové prevence a často nemají prostředky na zajištění služeb externích expertů (Briciu et al. 2012), byla identifikována jako mezera ve výzkumu, jejíž odstranění bude mít přínos i pro praxi.

Cílem výzkumu, jehož výsledek je zde prezentován, bylo na základě teoretických znalostí a za spolupráce s experty $\mathrm{z}$ oblasti krizového managementu vytvořit rámec postupu pro tvorbu systému krizového managementu. Postup je určen primárně, nikoli však výlučně, malým organizacím. Jejich manažeři tak dostávají do rukou námět, jak se systematicky připravovat na 
krizi, a to bez vyšších nákladů na pomoc externích agentur. Bez nich se však, v případě základního nedostatku vlastních znalostí a schopností, zřejmě zcela neobejdou. Postup je zde prezentován ve zkrácené verzi tak, aby upozornil na hlavní prvky a jejich provázanost.

\section{Metody}

Po rozsáhlém literárním výzkumu byly stanoveny dvě premisy: Pro vytvoření metodiky je zapotřebí chápat krizový management systémově a procesně. Na krizový management tedy bude pohliženo jako na celek složený z částí, které na sebe vzájemně působí. Mezi částmi systému mohou probíhat toky, $v$ našem př́padě informací a zdrojủ. Dále je uvažováno $s$ tím, že krizový management se jako proces skládá ze subprocesů, v nichž existují provázané dílčí aktivity.

Pro zachycení problematiky krizového managementu, jeho struktury, dílčích procesů a aktivit se jevilo nejvhodnější využít myšlenkovou mapu. V myšlenkové mapě jsou identifikovány jednotlivé klíčové pojmy, jež jsou asociačními podněty umožňujícími vybavit si celkovou informaci. Navzájem propojené pojmy jsou seřazovány v předem určeném sledu, díky kterému je asociační řetězec vytvářen. V koncepci myšlenkových map je jasně patrná metoda řetězení.

Výzkumný tým na základě myšlenkové mapy dedukoval logický sled hlavních prvků tvořících celý systém (proces) krizového managementu tak, aby byla zachycena jejich propojenost. $\mathrm{V}$ rámci indukce na základě posouzení experty z oblasti krizového managementu byla vytvořena konečná verze myšlenkové mapy, která byla použita jako východisko pro návrh rámce postupu. Předložená verze je otevřena pro další připomínky.

\section{Teoretická východiska řešené problematiky}

Ve zkoumání, ale také v praktickém vytváření systému krizového řízení, existuje řada bariér, omezení, se kterými se musí vědci i praktici vypořádat (Omorede 2020). Studie ukazují, že pouze neuspokojivé procento organizací, obvykle kolem $50 \%$, má sestaven krizový plán, a dokonce ještě méně organizací jej aktualizuje a testuje (Coombs 2015). Neočekávaným problémem se může stát ne nedostatek, ale naopak díky technologiím a rychle se rozvíjejícím databázím přebytek informací (Bartusková et al. 2015). Někdy management nedokáže identifikovat varovné signály (Schein 2010). Existují i př́pady, kdy se manažeři pokusí zakrýt nebo zkreslovat fakta (Sahin et al. 2015). Problémem mohou být i např. spory mezi odděleními, které mohou vést k vytváření úmyslných bariér (Mitroff, Alpaslan 2014). V př́pravě na krizi hrají velkou roli i finanční náklady (Briciu et al. 2012). Mikušová (2013) tvrdí, že potenciální právní náklady mají tendenci ovlivňovat způsob reakce organizace na krizi. Coombs (2015) upozorňuje na fakt, že ne každá krize je spuštěna „problémem“. Organizace by měla mít svá kritéria pro vymezení, kdy ,problém“ může přerůst do krize (Yiannaki 2012). Včasné převzetí odpovědnosti za krizový management je jedním z jeho rizikových faktorů (Detore 2017). Krizový management je samostatnou disciplínou se strategickým rozsahem a významem daleko přesahujícím ,pouhé“ včasné varování př̀i prevenci (Bénaben 2016). Je však rovněž zřejmé, že obě disciplíny zahrnují činnosti s cílem pomoci identifikovat problémy včas a efektivně je řídit tak, aby byla zredukována šance, že se ,problém“ stane krizí.

Významnými podněty k rozhodnutí vytvořit jednoduchý rámec pro postup byla i následující zjištění: Nechut' zavádět krizový management je často skrývána za různými obrannými mechanismy (Karim 2016). Nicméně uznávání vlastní zranitelnosti je v posledních letech na vzestupu (Mitroff, Alpaslan 2014). Bohužel často dojde k situaci, že při rozhodnutí pro zavedení a využívání krizového managementu jsou organizace konfrontovány s neznalostí postupu (Karim 2016). 
4 Rámec pro tvorbu systému krizového managementu v organizaci 4.1 Myšlenková mapa systému krizového managementu organizace

Nejdříve byly identifikovány prvky první úrovně. Byly nazvány: základní pojmy, podmínky pro zavedení krizového managementu, krizový profil organizace, strategie krizového managementu a procesy. Při jejich identifikaci bylo postupováno podle jejich logické návaznosti. Nejdř́ve je třeba precizovat, jak chápe krizi daná organizace a jak ji odlišuje od hrozby či problému a co pro ni představuje krizový management. Po akceptaci pojmů se lze posunout k otázce, jaké podmínky potřebuje organizace, aby byla ochotna a schopna se na krize připravovat. Dalším krokem je stanovení krizového profilu samotné organizace, tedy stupně její zranitelnosti, ohrožení různými typy krizí. Poté lze přejít ke strategiím zvládání krizí. Strategie budou odlišné v závislosti na typu krize a jejích atributech. Posledním prvkem první úrovně je samotný proces krizového managementu, který je podrobněji zkoumán v nižších úrovních.

Prvky první úrovně se dále rozpadají na úrovně nižší dva až čtyři. Souhrnným grafickým vyjádřením všech úrovní je myšlenková mapa systému krizového managementu v organizaci prezentovaná v Př́loze č. 1. Tímto způsobem je zachycena logická návaznost jednotlivých úrovní a provázanost jednotlivých prvků na těchto úrovních.

\subsection{Prvky a postup při tvorbě systému krizového managementu}

Př́i tvorbě metodiky bylo vycházeno z myšlenkové mapy, jejíž úrovně a prvky na nich určují logickou posloupnost postupu. Pro zachování rozsahu př́spěvku je zde v tabulkách prezentován pouze v krátkosti popis jednotlivých úrovní a prvků tak, aby byl zřejmý důvod a cíl každé akce, osoby odpovědné za její provedení a určení doby provedení. Požadované zdroje jsou stanoveny pouze rámcově. Obrázky jsou součástí myšlenkové mapy uvedené v prŕíloze.

\subsubsection{Základní pojmy}

Nebezpečí bývá v odborné literatuře i praxi odlišně definováno a chápáno. Podle mezinárodní specifikace OHSAS 18001:1999 je nebezpečí definováno jako zdroj nebo situace s možností způsobit škodu. Nebezpečí je fenomén, který má potenciál způsobit škodu. Hrozba představuje zdroj nebezpečí, který rovněž může způsobit škodu. Oba pojmy bývají často používány ve stejném významu. Hrozba je jakýmkoliv fenoménem, který má potenciální schopnost poškodit zájmy, znemožnit dosažení cílů nebo dokonce ohrozit existenci. Může vyplynout z negativní mimořádné události, která díky škodlivému působení jevů vyvolaných člověkem, př́rodou či technickými nebo technologickými haváriemi naruší stabilitu systému. Problém, jako nevyřešený nebo nežádoucí stav může být také zdrojem krize. Stěžejním úkolem organizace, která se rozhodne být proaktivní ve vztahu k potenciálním krizovým událostem, je stanovit si, co považuje za krizi, co ji odlišuje od problému, hrozby či mimořádné události, která může mít i závažný dopad na existenci organizace, a jak vymezí krizový management. Odlišení od jiných pojmů používaných $v$ managementu a identifikace vazeb $\mathrm{s}$ dalšími souvisejícími pojmy, tj. určení hranice krize, nehody, mimořádné události či problému, je zásadním výchozím krokem pro tvorbu systému krizového managementu (dále jen SKM) (Tab. 1).

Tabulka 1: Základní pojmy

\begin{tabular}{ll}
\hline Cíl & Definice pojmu krize, problém, krizový management \\
\hline Důvod & Vymezení chápání uvedených pojmů \\
Kdy & Úvodní fáze rozhodování o tvorbě SKM \\
Kdo & Tým odpovědný za tvorbu systému krizového managementu \\
Zdroje & Záznamy o nehodách, závažných problémech a jejich důsledcích \\
\hline
\end{tabular}

Zdroj: vlastní zpracování autora 
Definice pojmů bude v různých organizacích odlišná, nebot' bude vycházet ze specifik dané organizace. Obecně však krizi bude odlišovat od závažného problému větší závažnost dopadu (směřující až k potenciálnímu ukončení činnosti organizace) a délka potřebná $\mathrm{k}$ jejímu vyřešení. Při definování krizového managementu je obvykle včleňován již proces prevence, který probíhá souběžně se standardním řízením. Definice základních pojmů je součástí úvodní části krizového plánu.

\subsubsection{Podmínky pro zavedení krizového managementu}

Pro tvorbu, implementaci a efektivní využívání SKM musí být v organizaci vytvořeny vhodné podmínky (Obr. 1).

Obrázek 1: Podmínky pro zavedení krizového managementu

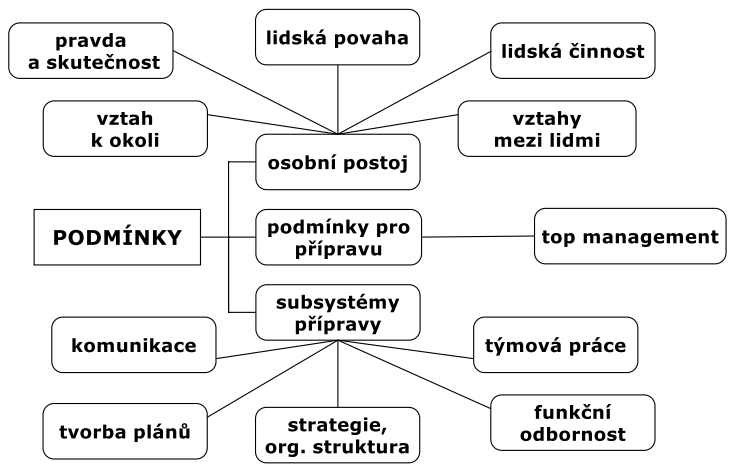

Zdroj: vlastní zpracování autora

Především je vyžadován široký rozsah odborných znalostí a dovedností z různých disciplín a patřičné infrastrukturální zázemí. Těmto podmínkám však předchází první, kterou je samotné rozhodnutí manažera/top managementu krizové události předjímat a ochota se na ně preventivně připravovat. Úlohou top managementu je toto rozhodnutí aktivně podporovat. Teprve poté jsou identifikovány znalosti a dovednosti potřebné pro zvládání krizových událostí. Úspěšnost propojení těchto tří úrovní podmínek se projeví v průběhu potenciální krize (Tab. 2).

Tabulka 2: Podmínky pro zavedení systému krizového managementu

\begin{tabular}{ll}
\hline Cíl & Diagnostika stavu a mezer v podmínkách nutných pro vytvořeni SKM \\
\hline Důvod & Akceptace možnosti ohrožení organizace krizovou událostí \\
Kdy & Úvodní fáze rozhodování o tvorbě SKM \\
Kdo & $\begin{array}{l}\text { Tým odpovědný za tvorbu SKM na úrovni organizační a/nebo na úrovních vnitropodnikových } \\
\text { útvarú }\end{array}$ \\
Zdroje & $\quad$ Výsledky analýz vnitřního prostředí \\
\hline Zdroj: vlastní zpracování autora
\end{tabular}

\section{Osobní postoj manažera}

Vnitřní (osobní) prrístup manažera k prrípravě na krizovou událost je dán odpovědí na otázku: „Chci se na krizi připravovat?“ Jedná se spíše o psychologický podnět, nebot' některé stránky osobnosti jsou nevědomé, působí skrze názory člověka. Jedná se např. o vztah k okolí nebo tvorbu obranných mechanismů. Těmito mechanismy mohou být pocit vlastní dokonalosti, tudíž nám krize nehrozí; existence strategického partnera, který nás v krizi ochrání; krize je náhoda, tedy se nelze na ni připravit; krize se děje jen ostatním a další (Shrivastava 1993). Pro jejich odhalení lze doporučit otázky analyzující kulturu organizace (viz Schein 2010) (Obr. 2). 
Obrázek 2: Osobní postoj manažera

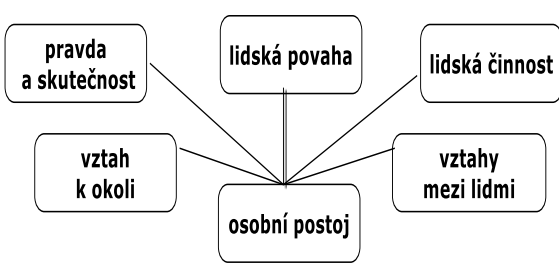

Zdroj: vlastní zpracování autora

Manažer si musí odpovědět na otázky typu: vcit’uji se do postavení ostatních, nepodceňuji jejich význam? Nebo se na ně dívám jen z hlediska toho, co mi mohou ostatní poskytnout? Může i náš podnik ohrozit krize? Možná jsme dost silní, aby nás ohrozila. Jen ti lidé, kteří mi neodporují, jsou „dobři'“? Jak se chovám (jsem aktivní, pasivní nebo odevzdaný osudu)? Lze krizi vůbec zabránit (při strategii fatalismu je snižován pocit viny a odpovědnosti)? Co je správný vztah mezi lidmi (spolupráce, soutěž, rivalita, individualismus)?

Na základě této sebeanalýzy si manažer (top management) sám musí uvědomit, zda je ochoten připustit si ohrožení potenciální krizí (Tab. 3).

Tabulka 3: Osobní postoj manažera

\begin{tabular}{ll}
\hline Cíl & Analýza vnitřniho př́stupu manažerů dle oblastí organizační kultury \\
\hline Důvod & Vědomí osobní odpovědnosti při př́pravě na krizové události \\
Kdy & Úvodní fáze rozhodování o tvorbě SKM \\
Kdo & Vrcholový management, střední management \\
Zdroje & Postoje, názory, zkušenosti vlastní a sdílené \\
\hline
\end{tabular}

Zdroj: vlastní zpracování autora

\section{Podmínky pro př́pravu na krizovou událost}

Jestliže $\mathrm{v}$ předchozím kroku manažer dojde $\mathrm{k}$ názoru, že je nutno přistoupit $\mathrm{k}$ prevenci krizových událostí, je zapotřebí, aby se top management $\mathrm{k}$ jeho snaze nestavil přezíravě. Předpokladem aktivní podpory preventivních snah je akceptace potenciální krize i ze strany top managementu (Tab. 4). V současné době, pokud top management překonal mentální obranné mechanismy, může jeho podporu ohrozit snad jen výše nákladů na vybudování SKM. Je pravda, že tyto náklady jsou neproduktivní, nepřinášejí žádný zisk. Avšak do budoucna mohou znamenat třeba i záchranu existence podniku. Jestliže se top management nebo majitel nepřenese přes tyto bariéry, přesvědčit jej mohou až vlastní zkušenosti s krizí. To však může být často pozdě.

Tabulka 4: Podmínky pro př́ípravu na krizovou událost

\begin{tabular}{ll}
\hline Cíl & Vytvoření podmínek pro připravu manažerů na krize \\
\hline Důvod & Nezbytnost podpory snah manažerů aktivně se připravovat na krizové události \\
Kdy & Úvodní fáze rozhodování o tvorbě SKM \\
Kdo & Vrcholový management \\
Zdroje & Postoje, názory, zkušenosti vlastní a sdílené \\
\hline
\end{tabular}

Zdroj: vlastní zpracování autora

\section{Subsystémy př́pravy na krizovou událost}

Po akceptování možnosti ohrožení potenciální krizovou událostí a zajištění podpory ze strany top managementu následuje identifikace a analýza oblastí, kam bude směrována př́prava a vzdělávání členů budoucích krizových týmů (Obr. 3). 
Obrázek 3: Subsystémy př́pravy na krizovou událost

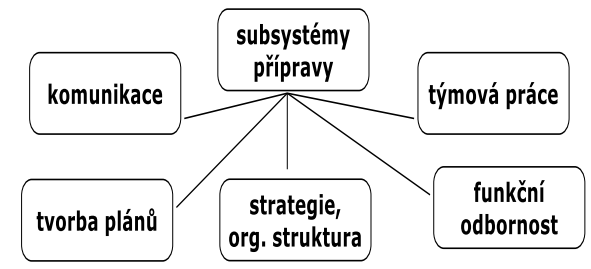

Zdroj: vlastní zpracování autora

Členové krizového týmu musí pravidelně procházet tréninkem zaměřeným nejen na jejich funkční odbornost, kreativitu, ale také na schopnost práce v týmu, komunikační zdatnost a psychickou odolnost. Pro svoji práci musí mít zajištěnou potřebnou infrastrukturu, která se opět bude odlišovat podle typu krize. Týká se např. zařízení místnosti, ve které bude tým v př́padě nutnosti pracovat, komunikačních prostředků, informační technologie, logistiky, zařízení, nástrojů apod.

Tabulka 5: Subsystémy př́ípravy na krizovou událost

\begin{tabular}{|c|c|}
\hline Cíl & Definování systému oblastí prípravy a vzdělávání \\
\hline Důvod & $\begin{array}{l}\text { Zajištění týmu odborníků připravených na zvládání krizových událostí včetně identifikování dalších } \\
\text { potrebných zdrojů }\end{array}$ \\
\hline Kdy & Po rozhodnutí stát se proaktivní organizací \\
\hline Kdo & Tým odpovědný za tvorbu SKM \\
\hline Zdroje & Výsledky analýz funkčních oblastí a požadovaných kvalifikací a kompetencí (gap analýza) \\
\hline
\end{tabular}

Zdroj: vlastní zpracování autora

\subsubsection{Krizový profil organizace}

Organizacím vyplývají hrozby z různých zdrojů. Například již samotný předmět jejich činnosti nebo produkty mohou být rizikové a mohou se stát př́íčinou krize (Obr. 4).

Obrázek 4: Krizový profil organizace

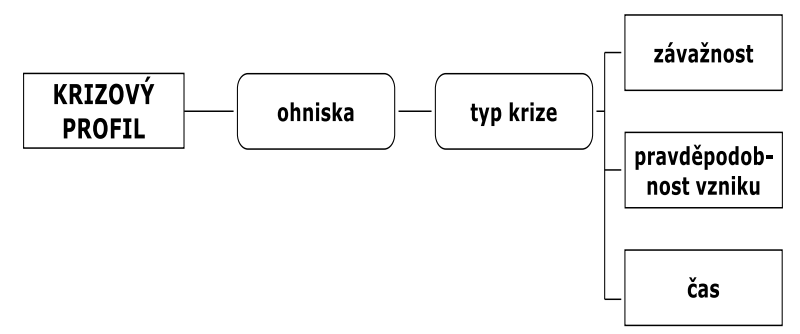

Zdroj: vlastní zpracování autora

Proces prevence začíná zjištěním rizikových oblastí. K jejich identifikaci slouží řada metod kvalitativních i kvantitativních. Relativně nejjednodušší jsou analýzy vnějšího a vnitřního prostředí, finanční analýza, faktorová nebo hodnotová analýza atd. Používají se i metody analýzy rizik jako např. bezpečnostní prohlídka, analýza ohrožení, analýzy stromu událostí nebo stromu poruch a další. Výsledkem analýz je nalezení možných ohnisek krizí (Tab. 6). Těmito ohnisky může např. závislost na jednom odběrateli či dodavateli, vysoký věk top managementu bez výchovy nástupců, zhroucení informačního systému, absence strategického plánování, ztráta klíčových zaměstnanců, vysoká zadluženost apod. 
Tabulka 6: Krizový profil organizace

\begin{tabular}{ll}
\hline Cíl & Zjištěni stavu ohroženosti (zranitelnosti) organizace \\
\hline Důvod & Akceptace potenciálního ohrožení při zpracovávání strategických záměrů \\
Kdy & $\begin{array}{l}\text { Na počátku a dále pravidelně v rámci procesu prevence na základě aktualizovaných dat nebo } \\
\text { nárazově při velké změně }\end{array}$ \\
Kdo & Tým odpovědný za tvorbu SKM, dále krizový tým ve spolupráci s funkčními manažery \\
Zdroje & Výsledky vnějších a vnitřních analýz
\end{tabular}

Zdroj: vlastní zpracování autora

\section{Ohniska potenciálních krizí}

Identifikovaná ohniska (hrozby, rizika) varují, ukazují na zranitelnost organizace. Neř́kají však, jaká krize může nastat. Proto je nutno v navazujícím kroku ohnisku přiřadit typ krize, která z tohoto ohniska může vzejít, čas, ve kterém se může ohnisko zaktivovat, závažnost škod, které může potenciální krize přinést, a pravděpodobnost, se kterou může ke krizi dojít. Názorně může být zranitelnost zachycena graficky v krizových maticích různého typu (Tab. 7).

Tabulka 7: Ohniska potenciálních krizí

\begin{tabular}{ll}
\hline Cíl & Identifikace ohrožených procesů, útvarů \\
\hline Důvod & Volba a nasměrování preventivních akcí \\
Kdy & Na počátku a dále průběžně v rámci procesu prevence na základě aktualizovaných dat, dále \\
& v průběhu ř́izení vývoje krize \\
Kdo & Střední management, tým odpovědný za tvorbu SKM, dále krizový tým \\
Zdroje & Výsledky vnějších a vnitřních analýz organizace, dále dle aktuálního vývoje krize
\end{tabular}

Zdroj: vlastní zpracování autora

\section{Typ krize}

Specifika každé organizace ovlivní typy potenciálních krizí. Ovlivňujícími specifiky mohou být např. předmět činnosti, stáří organizace, charakter trhu, použivaná technologie, požadovaná kvalifikace pracovníků, organizační struktura, styl řízení a řada dalších. Samozřejmě nelze podchytit všechny typy krize, avšak na konvenční, předvídatelné krize by organizace měla být připravena. Užitečné je rozlišovat alespoň mezi několika typy krizí, a to krizí ekonomickou, interpersonální, související s organizační kulturou a společenskou nebo environmentální krizí se spouštěči jako je např. korupce, případně technickou či technologickou krizí způsobenou haváriemi, výrobou nebezpečných produktů aj. Identifikované typy je dále zapotřebí vyhodnotit podle pravděpodobnosti jejich vzniku, závažnosti jejich dopadu na organizaci (negativní až zničující), intenzity působení a možného časového horizontu jejich vzniku. Poté je viditelný krizový profil organizace a je možno volit mezi strategiemi prŕstupu k jednotlivým typům krizí. Obecně lze některá ohniska odstranit a tímto zamezit vzniku krize, na některé krize se lze preventivně připravit a další skupinou jsou typy krize, které budou řešeny až v okamžiku, kdy k nim skutečně dojde (Tab. 8).

Tabulka 8: Typ krize

\begin{tabular}{ll}
\hline Cíl & Získání informací o potenciálních krizích dle jejich typu a vlastností \\
\hline Důvod & Př́prava preventivních opatření zaměřených na daný typ krize \\
Kdy & Na počátku a dále prüběžně v rámci procesu prevence na základě aktualizovaných dat, dále \\
& v průběhu ř́zení vývoje krize \\
Kdo & Tým odpovědný za tvorbu SKM, dále krizový tým \\
Zdroje & Výsledky analýzy ohnisek potenciálních krizí
\end{tabular}

Zdroj: vlastní zpracování autora 


\subsubsection{Strategie uplatňované v krizovém managementu}

Pro úspěšnou implementaci a využívání preventivních opatření a vedení krizového managementu je od top managementu vyžadována jasná deklarace podpory a zajištění zdrojů. Pro jejich efektivní využívání by měla mít organizace vyjasněny strategie uplatňované v krizovém managementu (Obr. 5).

Obrázek 5: Strategie uplatňované v krizovém managementu

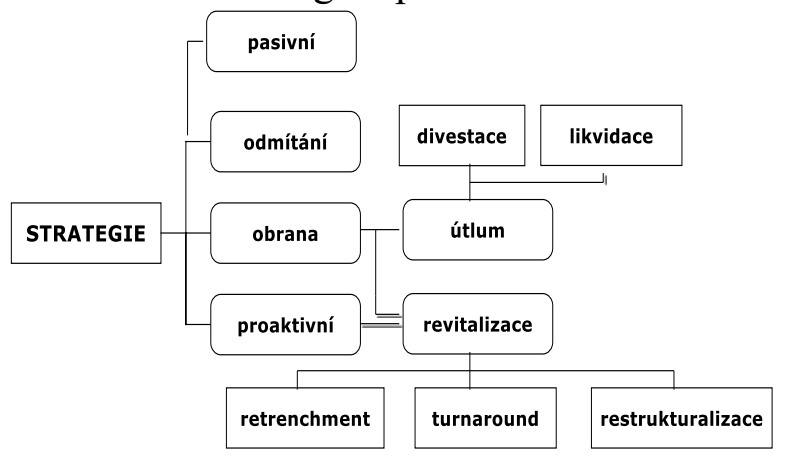

Zdroj: vlastní zpracování autora

Obecně lze uplatnit kombinaci čtyř základních strategií od odmítání existence krize, odmítání dialogu ke konstruktivnímu řešení až k pochopení krize jako výzvy. V rámci těchto obecných př́stupů je strategie konkretizována podle aktuálního stavu a vývoje krizové události. Původně zvolená strategie zvládání krize není neměnná. Formulované strategie směrují do dvou rovin. Jedna rovina znamená pozitivní variantu zachování organizace. Mủže být zachována bud'to v původním stavu, nebo může zaznamenat dokonce kladný posun po vývojové křivce. Druhá rovina znamená útlum směřující do úplného ukončení existence organizace (Tab.9).

Tabulka 9: Strategie uplatňované v krizovém managementu

\begin{tabular}{ll}
\hline Cíl & Formulace strategií \\
\hline Důvod & $\begin{array}{l}\text { Pochopení aspektů možných druhů strategií v souvislosti s žádoucími výsledky krizového } \\
\text { managementu }\end{array}$ \\
Kdy & $\begin{array}{l}\text { Při vzniku krizové události, možné změny v průběhu krize } \\
\text { Kdo }\end{array}$ \\
Tým odpovědný za tvorbu SKM, dále krizový tým \\
\hline Zdroje & Strategické cíle, výsledky analýz při identifikaci krize, dále výsledky analýz v průběhu krize
\end{tabular}

Zdroj: vlastní zpracování autora

\subsubsection{Procesy}

Krizový management lze obecně rozdělit na tři dílčí procesy: prevence, realizace vlastního krizového managementu $\mathrm{v}$ době krize a post krizové aktivity. Žádný z těchto procesů nesmí být proaktivní organizací podceňován. Výstupy jednotlivých procesů na sebe navazují a ovlivňují kvalitu procesu navazujícího.

\section{Prevence}

Problematika prevence je široká. Zahrnuje různé způsoby snižování rizika vzniku krizové události. V pojetí prezentované metodiky se tento dílčí proces zabývá predikcí krizové události, vytvořením báze metod používaných při analytické práci a pro tvorbu plánů a přípravou prvků ovlivňujících proces prevence (Obr. 6). 
Obrázek 6: Prevence

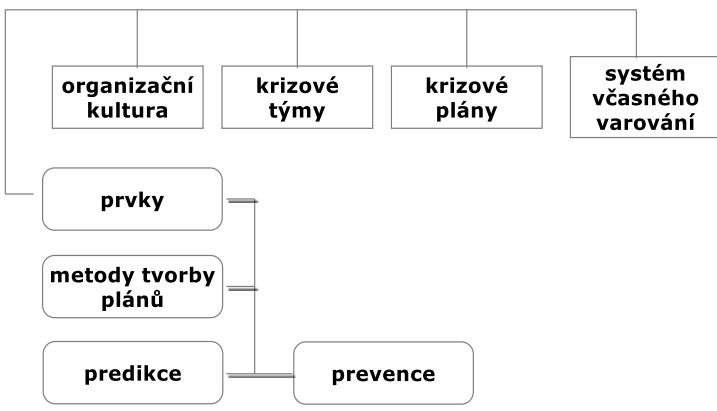

Zdroj: vlastní zpracování autora

Při volbě efektivního př́stupu k prevenci organizace vychází z identifikovaných ohnisek, př́padně $z$ vytvořené krizové matice. Účelem procesu je stanovit postup a náplň aktivit včetně jejich zabezpečení zdroji tak, aby bylo zamezeno vzniku krizové události; při nezabránění vzniku, aby organizace byla schopna rychle a efektivně jednat (Tab. 10).

Tabulka 10: Prevence

\begin{tabular}{ll}
\hline Cíl & Vytvoření a aktualizování preventivních opatření proti vzniku krize \\
\hline Důvod & Zajištění kontinuity činnosti organizace \\
Kdy & $\begin{array}{l}\text { Po identifikaci krizového profilu organizace, průběžná aktualizace } \\
\text { Kdo }\end{array}$ \\
Krizový tým za součinnosti středního managementu \\
Zdroje & $\begin{array}{l}\text { Strategický plán, strategie uplatñované v krizovém managementu, krizový profil organizace, } \\
\text { výstupy post-krizového auditu }\end{array}$ \\
\hline Zdroj: vlastní zpracování autora
\end{tabular}

\section{Predikce}

Součástí procesu prevence je permanentní diagnostika stavu organizace, včetně prognózování vzniku možné krizové události. Nejčastěji se vychází z finančních ukazatelů (zisk, rentabilita, likvidita, zadluženost), může být sledována výše druhových nákladů, fluktuace, zmetkovitost, obrat pohledávek nebo zásob, a dále ukazatele specifické pro každý podnik. (Tab. 11). Permanentní diagnostika je spojena s efektivně fungujícím systémem včasného varování.

Tabulka 11: Predikce

\begin{tabular}{ll}
\hline Cíl & Zamezení vzniku krizové události včasným zásahem \\
\hline Důvod & Relativně rychlé a neustálé změny uvnitř i vně organizace \\
Kdy & Průběžně \\
Kdo & Střední management, krizový tým \\
Zdroje & Podklady z funkčních oblastí podle typu krize, výstupy systému včasného varování \\
\hline
\end{tabular}

Zdroj: vlastní zpracování autora

Pro predikci vzniku krize v delším období, tedy ne v návaznosti na systémy včasného varování, lze použít řadu bankrotních modelů (např. Altmanův, Tafflerův, IN indexy), které mohou signalizovat ohrožení krizí s předstihem několika let.

\section{Tvorba krizových plánů - metody}

Každá organizace má více ohnisek potenciálních krizí, ze kterých mohou vzejít krize různých typů (Tab. 12). 
Tabulka 12: Tvorba krizových plánů

\begin{tabular}{ll}
\hline Cíl & Vytvořeni metodologické databáze pro tvorbu krizových plánu pro odlišné typy krizí \\
\hline Důvod & Organizaci mohou ohrožovat různé typy krizí, vyžadující odlišné zásahy \\
Kdy & Prűběžne \\
Kdo & Krizový tým ve spolupráci s experty \\
Zdroje & Výsledky aktivního vyhledávání informací a studia, učení se ze zkušeností vlastních i cizích \\
\hline
\end{tabular}

Zdroj: vlastní zpracování autora

Prvky (plán, tým, organizační kultura, systém včasného varování)

Obecná struktura krizového plánu: Stručný popis krizové situace a možnosti jejího výskytu, příčiny vzniku a odhad trvání. Scénář vývoje krizové situace: popis skutečností indikujících možný vznik krize, bezprostředně hrozící vznik, skutečný vznik krizové situace, trvání krizové situace (nedaří se ji stabilizovat, vyřešit), ukončení krize. Výčet potenciálních sekundárních krizí, kterou mohou vzniknout jako důsledek vzniku popisované krizové situace. Dopady vývoje krizové situace na životy a poškození zdraví osob, zničení a poškození majetku, životního prostředí, ekonomické a sociální dopady. Tato část může být obsažena v krizovém scénáŕi. V tomto príípadě by se krizový plán soustředil jen na následující část: Podmínky a omezení pro řešení krizové situace: krizový tým (způsob jeho svolání, komunikace, pravomoci), infrastruktura (hmotné a nehmotné prostředky, logistika), komunikační kanály vnitřní a vnější, požadavky na mimořádné prostředky, externí podporu. Doporučené postupy a zásady: požadovaný cílový stav, monitorování stavu, přenos informací, kdo bude obeznámen se situací (vnitřní a vnější zájmové skupiny), typové postupy a opatření realizovaná v době vzniku krizové situace, $v$ době řešení a v době po vyřešení krize.

Je pravdou, že se krize nemusí vyvíjet tak, jak bylo předpokládáno v krizovém plánu. Dobře vycvičený krizový tým a připravená organizační kultura má však větší šanci i tuto krizi zvládnout. Protože jsou krize různorodé, i složení týmů se bude měnit. Jsou krize, kdy nejdůležitějšími členy týmu bude daňový kontrolor, auditor a právník. Jiný typ krizí bude vyžadovat zastoupení hlavního technologa, odborníka na bezpečnost práce či logistika. U malých podniků obvykle jsou jejich majitelé či výkonný management také členy tohoto týmu. Př́prava krizového týmu má různé formy - od seznamování s aktuální verzí krizového plánu a souvisejících dokumentů, řešení krizových situací formou diskuse tzv. „u stolu“, kdy moderující zadává změny ve vývoji modelované situace, test v simulované probíhající situaci $\mathrm{v}$ reálném prostředí až po simulované testy trvající několik dnů.

Organizační kultura jako hodnoty (co je považováno za důležité, „dobré“ nebo „špatné“), postoje ke konkrétním dějům, zvyky, rituály se projevují v myšlení a zejména chování všech zaměstnanců v organizaci. Slabá organizační kultura může být sama o sobě zdrojem krize. Jestliže chce top management spoléhat na loajalitu zaměstnanců v době krize, nesmí neformální prostředí $\mathrm{v}$ podniku podceňovat.

Jestliže se organizace rozhodne odpovědně přistupovat k zajištění kontinuity své existence, obvykle zavádí tzv. systémy včasného varování, které včas signalizují nežádoucí odchylky od stanovených limitů (Tab. 13).

Tabulka 13: Prvky

\begin{tabular}{ll}
\hline Cíl & Efektivni reakce na vypuknutí krizové události \\
\hline Důvod & Zajištění kontinuity činnosti organizace \\
Kdy & Po stanovení podmínek pro zjištění krizové události, průběžná aktualizace \\
Kdo & Krizový tým \\
Zdroje & Podklady z funkčních oblastí podle typu krize \\
\hline
\end{tabular}

Zdroj: vlastní zpracování autora 


\section{Realizace krizového managementu}

Ideální by bylo zahájit krizový management již v latentní fázi krize. Bohužel k tomu velmi často nedochází. Důvodem bývá absence systému včasného varování nebo jeho špatné nastavení. Podmínkou úspěšných zákroků krizového týmu je dostatek požadovaných zdrojů (finančních, technických atd.), nástrojů, metodik a kvalitně připravený krizový tým (Tab. 14).

Tabulka 14: Realizace krizového managementu

\begin{tabular}{ll}
\hline Cíl & Ukončení krize \\
\hline Důvod & Krize organizaci rozkládá, ohrožuje její existenci \\
Kdy & Po identifikaci krize \\
Kdo & Krizový tým \\
Zdroje & Krizový plán, strategický záměr, aktuální informace o dopadech krize \\
\hline
\end{tabular}

Zdroj: vlastní zpracování autora

\section{Aktivity po skončení krize}

Třetí dílčí proces krizového managementu si zaslouží pozornost rovnocennou procesům předchozím. Každá krize je zdrojem poučení (Obr. 7).

Obrázek 7: Aktivity po skončení krize

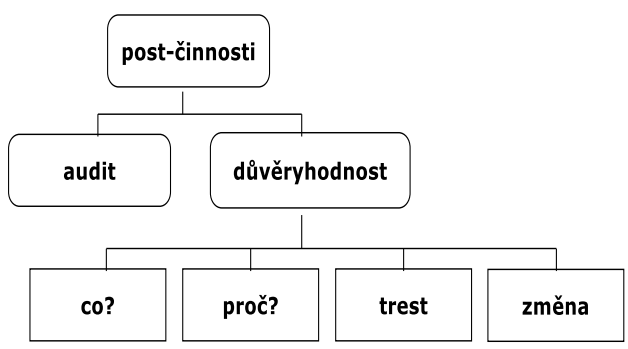

Zdroj: vlastní zpracování autora

Odpovědně vyhodnocený proces krizového managementu znamená analýzu akcí a reakcí a jejich výsledků, analýzu chování členů krizového týmu i zaměstnanců obecně a další. Rozhodně se nesmí zúžit pouze na hledání viníků (Tab. 15).

Tabulka 15: Aktivity po skončení krize

\begin{tabular}{ll}
\hline Cíl & Zkvalitnění procesu prevence \\
\hline Důvod & $\begin{array}{l}\text { Identifikace nových prvků, které dříve nebyly brány v úvahu, } \\
\text { a nedostatků, které je třeba odstranit. }\end{array}$ \\
Kdy & $\begin{array}{l}\text { Po skončení krize } \\
\text { Kdo }\end{array}$ \\
Krizový tým, top management \\
Zdroje & $\begin{array}{l}\text { Výsledky analýzy dopadů krize, záznamy z jednání během krize, tiskové zprávy, záznamy z jednání } \\
\text { se stakeholdery }\end{array}$ \\
\hline Zdroj: vlastní zpracování autora
\end{tabular}

\section{Pokrizový audit}

I v př́padě pravidelné aktualizace krizového plánu a kvalitního výcviku členů krizového týmu dochází k výkyvům, odchylkám, chybám a novým skutečnostem. Audit po skončení krize by měl přispět k jejich zjištění a pozdějšímu odstranění tak, aby organizace byla lépe připravena na krizi budoucí (Tab. 16). 
Tabulka 16: Pokrizový audit

\begin{tabular}{ll}
\hline Cíl & Zjistit mezeru mezi skutečností a požadovaným stavem preventivních opatrení \\
\hline Důvod & V době krize působí nečekané/neplánované faktory \\
Kdy & $\begin{array}{l}\text { Po skončení krize } \\
\text { Kdo }\end{array}$ \\
$\begin{array}{l}\text { Krizový tým, top management, př́padně externí expert } \\
\text { Záznamy průběhu krize, výsledky analýzy dopadů krize, vnímání krize zaměstnanci i externím } \\
\text { okolím }\end{array}$ \\
\hline Zdroj: vlastní zpracování autora
\end{tabular}

Zdroj: vlastní zpracování autora

\section{Znovuzískání důvěryhodnosti}

Přesvědčit zaměstnance, dodavatele, zákazníky, banky a další subjekty o skutečnosti, že organizace krizi zvládla a je schopna dostát všem závazkům, nebude jednoduché. Musí uspokojivě odpovědět na klíčové otázky stakeholderů jako jsou: co se stalo, proč k situaci došlo, jak situace organizaci postihla a jaké změny organizace provedla (Pfaffer et al. 2008). Organizace musí počítat se skutečností, že bude nyní okolím posuzována přísněji a že budoucí problémy mohou být okolím nebo zaměstnanci posuzovány neadekvátně jako přehnaně důležité (Tab. 17).

Tabulka 17: Znovuzískání důvěryhodnosti

\begin{tabular}{ll}
\hline Cíl & $\begin{array}{l}\text { Obnoveni důvěryhodnosti organizace pro zaměstnance } i \text { okolí, tímto si vytvořit podmínky pro } \\
\text { návrat na trh }\end{array}$ \\
\hline Důvod & Krize narušila vztahy se zaměstnanci i externími subjekty \\
Kdy & Během krize, po skončení krize \\
Kdo & Krizový tým, top management, externí expert \\
Zdroje & Výsledky analýzy dopadů krize na vnímání organizace zaměstnanci a okolím \\
\hline
\end{tabular}

Zdroj: vlastní zpracování autora

\section{Závěr}

Článek reflektuje na aktuální situaci malých organizací. Neustále se měnící podnikatelské prostředí společně se současným ekonomickým ohrožením dopadá negativně se zvýšenou měrou právě na malé organizace a netýká se to pouze aktuální pandemické situace.

Výzkum, jehož výsledek je zde prezentován, vychází ze zjištění, že manažeři malých organizací chápou zranitelnost a často by se chtěli připravovat na ohrožení krizemi. Narážejí však na bariéru tvořenou nedostatkem zdrojů, a to především finančních a znalostních. Zde byla identifikována mezera ve výzkumu i praxi. Byl stanoven cíl - vytvořit bázi prvků a identifikovat vztahy mezi nimi tak, aby bylo možno vytvořit rámec pro vytvoření systému krizového managementu v organizaci, tzn. zdůraznit klíčové oblasti, které nesmí být opomenuty.

Byl proveden rozsáhlý literární výzkum. Zde je uveden jen velmi malý výsek publikací. Na základě takto zjištěných skutečností byl ve spolupráci s krizovými manažery za použití myšlenkové mapy vytvořen prezentovaný rámec. Jednoduchý a srozumitelný rámec pro vytvoření systému krizového managementu je podanou rukou manažerům. Aplikace v několika malých organizacích potvrdila jeho praktickou využitelnost.

\section{Poděkování}

Tento článek byl zpracován s podporou SGS projektu na Ekonomické fakultě VŠB-Technické univerzity Ostrava č. SP2020/33. 


\section{Literatura}

[1] BARTUSKOVÁ, T., M. PAPALOVÁ and A. KRESTA, 2015. Selection of a forecasting method: analytical hierarchy process approach. In Scientific Papers of the University of Pardubice, Series D, XXII(34), 17-28.

[2] BÉNABEN, F., 2016. A formal framework for crisis management describing information flows and functional structure. Procedia Engineering, 159, 353-356.

[3] BERGERON, C. D. and F. COOREN, 2012. The Collective Framing of Crisis Management: A Ventriloqual Analysis of Emergency Operations Centres. Journal of Contingencies and Crisis Management, 20(3), 120-137.

[4] BRICIU, S., C. GROZA and A. PUȚAN, 2012. Small business development during the crisis. Annales Universitatis Apulensis series Oeconomica, 14(2), 320-333.

[5] COOMBS, T. W., 2015. Ongoing Crisis Communication. 4th ed. Thousand Oaks: Sage.

[6] DETORE, D., 2017. Disaster expert: Leaders must acknowledge crisis. Tire Business [online]. 35(14), 0011-11 [cit. 2020-05-15], dostupné na: http://search.ebscohost.com/login.aspx?direct=true

[7] KARIM, A. J., 2016. The Indispensable styles, characteristics and skills for charismatic leadership in times of crisis. International Journal of Advanced Engineering, Management and Science, 2(5), 363-372.

[8] MIKUŠOVÁ, M., 2013. Do small organizations have an effort to survive? Survey from small Czech organizations. Ekonomska istraživanja - Economic Research, (26)4, 59-76.

[9] MITROFF, I I. and C. M. ALPASLAN, 2014. The crisis-prone society: a brief guide to managing the beliefs that drive risk in business. London: Palgrave Pivot.

[10] OMOREDE, A., 2020. Managing crisis: a qualitative lens on the aftermath of entrepreneurial failure. International Entrepreneurship and Management Journal. https://doi.org/10.1007/s11365-020-00655-0.

[11] PFAFFER, M. D., K. A. DECELLES, K. G. SMITH and M. S. TAYLOR, 2008. After the fall: Reintegrating the Corrupt Organization. Academy of Management Review, 33(3), 730748 .

[12] SHRIVASTAVA, P., 1993. Crisis theory/practice: towards a sustainable future. Industrial and Environmental Crisis Quaterly, 7(1), 23-42.

[13] SAHIN, S., S. ULUBEYLI and A. KAZAZA, 2015. Innovative crisis management in construction: Approaches and the process. Procedia - Social and Behavioral Sciences, 195, 2298-2305.

[14] SCHEIN, E., 2010. Organizational Culture and Leadership. 4th ed. Jossey-Bass.

[15] YIANNAKI, S., 2012. A systemic risk management model for SMEs under financial crisis. International Journal of Organizational Analysis, 20(4), 406-422.

[16] ZAPLETALOVÁ, Š., L. MEIXNEROVÁ, M. MENŠÍK, V. PÁSZTO and E. SIKOROVÁ, 2015. Character of Entrepreneurial Subjects in Olomouc Region. Ekonomika Management Inovace, 7(3), 21-31.

[17] OHSAS 18001:1999 
Př́loha 1: Myšlenková mapa systému krizového managementu

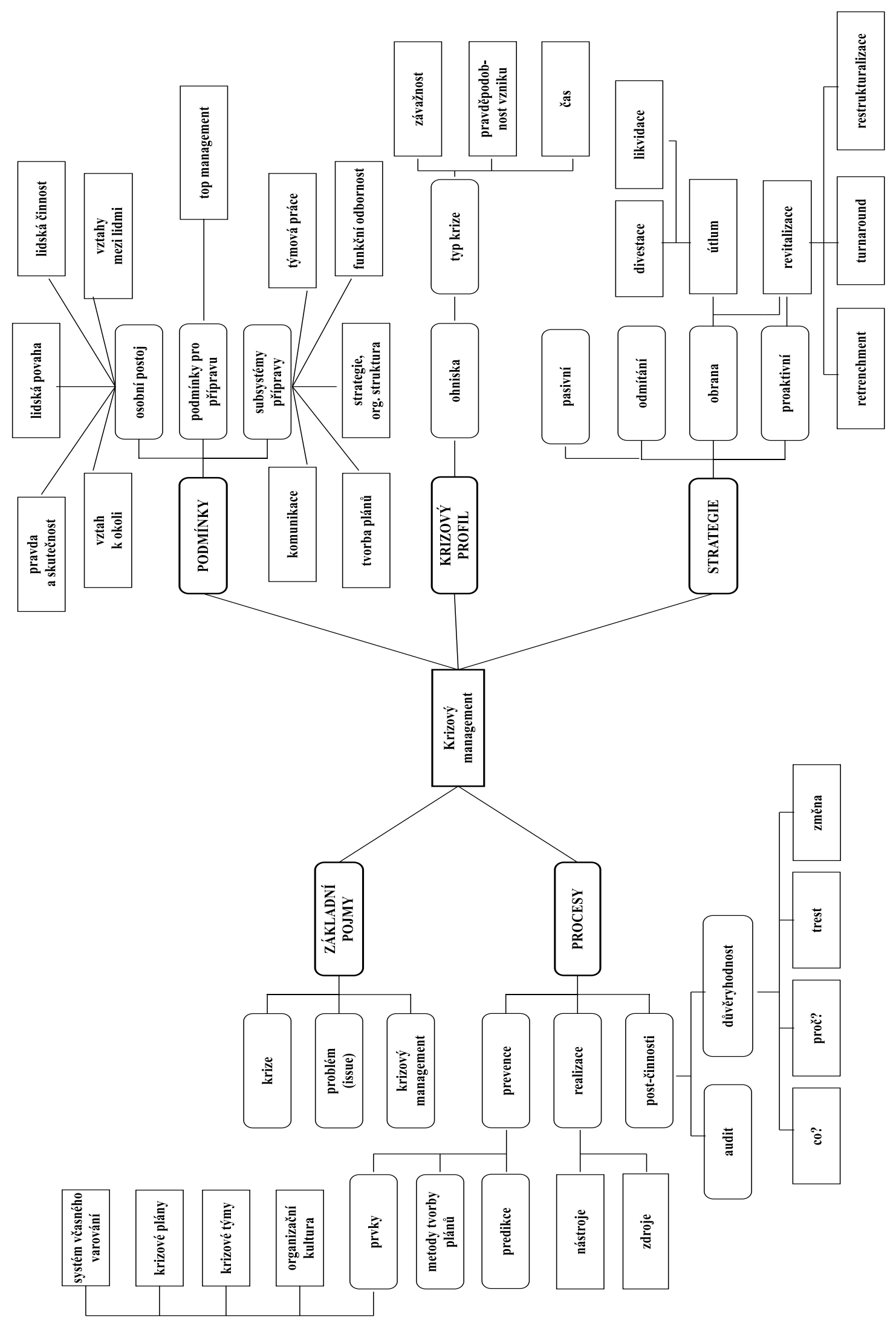

Zdroj: vlastní zpracování autora 